Symposium 19: "Evolução do ensino de Bioquímica nos últimos 20 anos"

\author{
Chair: Vera Treis Trindade
}

Bayardo Torres; Clovis Wannmacher; Denise Macedo

\title{
S19-1. The contributions of the Department of Biochemistry/USP towards Biochemistry teaching
}

\section{O ensino de Bioquímica nos últimos 20 anos}

Bayardo B. Torres

Departamento de Bioquímica, Instituto de Química, USP. São Paulo, Brazil.

Abstract: Among the contributions of the Department of Biochemistry/USP one must recall:

1. Winter school for graduate students

This course, now at the ninth edition, is intended for students in the final stage of their Masters or PhD in Biochemistry or related areas from any institution of higher education.

Modern and important techniques are offered as possible support to help the student's projects.

2. Summer courses for undergraduate students

The Department offers every year, since 1999, complementary courses for undergraduate students to extend their knowledge in biochemical subjects not ordinarily treated in introductory courses. Some examples:

Plant Molecular Biology, Biochemistry and Diseases, Biochemistry of Mind, Biochemistry of Ageing, Cancer Biochemistry, Nutrition and Sports, Biochemistry of Beauty, Biochemistry of the Envenomation Response, etc.

3. Summer courses for high school teachers. Some examples:

Biochemistry of Nutrition, DNA - Techniques and Applications, Biochemistry in the kitchen.

4. Software development

Many software for biochemistry teaching/learning were developed and are freely available at the Biblioteca Digital de Ciências [http://www.bdc.ib.unicamp.br]. Some examples:

Oxygen consumption by mitochondria, Muscle contraction, Electron transport chain and oxidative phosphorylation, Free radicals, Enzyme kinetics, cAMP signalization, Interactive study of protein structure, Leptin, Insulin and Obesity.

5. A Biochemistry textbook. 